\title{
Environmental Efficiency in Water Use in Offshore Platforms in Campos Basin-RJ-Brazil
}

\author{
Victor Duarte, Asher Kiperstok, Luciano Queiroz, Ednildo Torres \\ Federal University of Bahia, Salvador, Brazil \\ Email: prema2023@hotmail.com
}

Received 7 April 2015; accepted 20 June 2015; published 23 June 2015

Copyright (C) 2015 by authors and Scientific Research Publishing Inc.

This work is licensed under the Creative Commons Attribution International License (CC BY). http://creativecommons.org/licenses/by/4.0/

(c) (i) Open Access

\begin{abstract}
In drilling and production of oil at sea, potable water is most commonly transported to oil platforms using offshore supply vessels (OSV). This transport generates a series of environmental impacts, such as the emission of greenhouse gases and risks to human health. Furthermore, transporting high volumes of water requires large vessels and consequently, very high fuel consumption. To minimise the environmental impacts, water supply options were studied. The desalination of seawater and the reusing of streams from grey water (light and dark) and black water were evaluated and compared with the characteristics of the current supply via OSV. The amount of fuel consumed was collected in the logistics department of the oil company that used the OSVs. Air emissions were quantified using the methodology that the IPCC recommended. The information on the types of sewage treatment was found in the technical manuals from the manufacturers. It was concluded that the reused water could achieve up to $70 \%$ reduction in atmospheric emissions, the use of chemicals in the water treatment plant, sludge generation and the consumption of marine diesel fuel for the transport of water. On the other hand, the same reduction can be observed both from the effluent disposal at sea and in the chlorine of the sewage treatment plant. Therefore, the source of water used and the reduction of air emissions can be maintained without impairment of the normal water use in offshore platforms in the Campos Basin. The objective of this study was to diagnose problems related to the current form of water supply, to quantify them and to propose measures for increasing environmental efficiency.
\end{abstract}

\section{Keywords}

Offshore Supply Vessels, Water Reusing, Wastewater Treatment, Air Emissions 


\section{Introduction}

Every day, offshore oil platforms use large amounts of water in their activities related to oil exploration and production in the sea. Usually, the drinking water used comes from a drinking water treatment station on land and is transported by 23 offshore supply vessels (OSV) from the collected point to the 60 offshore platforms in the Campos Basin [1]. These platforms are about 112 miles from shore. The seawater is also collected and used for less noble activities, such as flushing toilets.

Supplying water via OSV is a complex operation because it depends directly on weather and navigation compatible with the characteristics of the vessel type. Thus, sometimes a reduced water supply due to shipping difficulties can result in the stoppage of drilling activities for days, representing a significant loss due to the high costs of a platform.

The OSV used in water transport generates maritime emissions that are important on the local, regional and global scales, with local air pollution being one of the most important externalities of shipping. Its effects are acute in urban areas as a result of the manoeuvres, the round trip to and from the platforms, and even in cargo handling activities at the pier [2].

Each offshore oil rig has a wastewater treatment plant (WWTP). These treatment plants are devices designed to remove the physical impurities, chemical and pathogenic organisms as much as possible, preparing the effluent to be released into the sea in view of the provisions of environmental legislation (national and international).

The desalination and reusing processes have been adopted in many countries as a way to meet the growing demand for water, the lack of surface and underground water sources and their preservation. However, in the case of offshore platforms, the most widely used alternative to reduce dependency on OSV to supply water is seawater desalination. In this particular case, water reusing was proposed as a way to not only reduce atmospheric emissions from marine diesel oil (MDO) combustion, but to also avoid problems related to large amounts of seawater desalination.

The technology currently available allows for the reusing of both grey water and black water streams in offshore oil platforms. It is hoped that the reused water can be used for the same types of applications as the water was initially used for, such as bathing, washing clothes, flushing toilets and deck cleaning. Only the kitchen water is not reused for the same purpose due to processing difficulties. However, it can be sent to a biological Wastewater Treatment Plant (WWTP) and after treatment, it would meet the demands for industrial water or it could be discarded at sea. However, to be able to reuse the water from the grey water and black water streams, it is necessary to fulfil the technical requirements of water quality in each reuse through the use of specific treatment technologies.

To make better use of water, it is essential that the reusing project separate the streams of black water, light grey water and dark grey water. In addition, in order for the recovery of the physical and chemical characteristics of the water to become compatible for use in various applications, effective disinfection of the effluent is necessary to ensure that pathogens are inactive and to ensure that if a person accidentally makes contact with the effluent under conditions of risk, there is not any possibility of biological contamination.

The objective of this work was to diagnose environmental problems related to the current water supply, quantify them and propose measures to increase environmental efficiency in the chain of exploration and production of oil related to the water supply for offshore platforms of Campos Basin in Rio de Janeiro, Brazil.

\section{Study Case}

The water supplied to the platforms comes from the Macae River 12.5 miles from the Water Treatment Plant (WTP). The water is pumped processed for placing in the OSV tanks. In 2013, the WTP generated $0.06165 \mathrm{~kg}$ of sludge per $\mathrm{m}^{3}$ of water for 1,095,000 $\mathrm{m}^{3}$ of water supplied to the 60 offshore oil platforms. In all, a total of 67.5 tons of sludge was produced. During the water treatment process, aluminium sulphate was used at a concentration of $0.04325 \mathrm{~kg} / \mathrm{m}^{3}$, with 47.4 tons used in 2013 .

Petróleo Brasileiro S/A Petrobras has a pier in Macaé City, Rio de Janeiro, Brazil for water loading and other products, such as food, chemicals and equipment, for shipping to the platforms via OSVs.

Transport logistics by OSVs to the offshore platforms have many limitations, mainly regarding weather conditions and navigation. The uncertainties cause challenges in scheduling and running deliveries to the platforms, and it is often difficult to secure frequent use of OSVs based on a deterministic plan [3].

Each OSV should be able to carry enough drinking water to supply up to four platforms in order to reduce the 
very high costs for this type of transport. The uncertainties regarding weather and navigation conditions result in frequent OSV schedule changes [3]. When loaded with water, the OSVs are required to use the maximum engine power up to the point of final distribution, consuming large amounts of fuel. When the OSV is empty and returns to the pier, the consumption of marine diesel oil (MDO) is much lower [4].

In the ports/pier, the vessels' engines are left running, not only to provide power for lights, electronics, etc., but also to operate cranes and pumps that perform loading and unloading operations. This contributes to the deterioration of local air quality, either by direct emission of pollutants, for example, CO or PM (suspended particulate matter), or because of increased production of secondary pollutants (those formed in the atmosphere as a result of chemical reactions involving primary pollutants), such as $\mathrm{O}_{3}$, from the emission of precursor species $\left(\mathrm{NO}_{\mathrm{x}}\right)$ [5]. Efforts to reduce $\mathrm{CO}_{2}$ and other pollutants that have been emitted by OSVs should be considered based on research that has already been carried out. This research has taken into account the reduction of emissions due to long-range propagation of these pollutants, their impacts on human health and the climate, and the favourable cost-benefit of reducing these pollutants [6].

Sulfur dioxide emissions are essentially a function of the sulfur content in the fuel. In the case of marine petroleum fuels, $\mathrm{SO}_{2}$ emissions are high due to the high sulfur content, which can range from less than $0.3 \%$ to more than 5\% [7]. The MDOs supplied to the OSVs in Brazil have a sulfur content of about $1 \%$ of their weight or 10,000 ppm of sulphur, as described in its MSDS of the BR Distribuidora [8]. Thus, for every $100 \mathrm{~kg}$ of fuel oil, $1 \mathrm{~kg}$ of sulphur is generated. The burning of the fuel emits sulfur, which reacts with oxygen to form $\mathrm{SO}_{2}$ [9]. The diesel engines on vessels produce particles as part of their emissions. The gaseous sulfur dioxide $\left(\mathrm{SO}_{2}\right)$ and nitrogen oxides $\left(\mathrm{NO}_{\mathrm{x}}\right)$ vessels are converted into aerosols $(\mathrm{PM})$, sulphate $\left(\mathrm{SO}_{4}\right)$ and nitrate $\left(\mathrm{NO}_{3}\right)$, particularly in the summer [10]. They can then be transported hundreds of miles on land [7] [11] [12].

Small amounts of methane $\left(\mathrm{CH}_{4}\right)$ can be produced when hydrocarbons in the fuel are not completely burned. The methane content of the fuel, the type of engine, the amount of unburned hydrocarbons from the engine and the afterburning emission controls influence methane emissions [13]. Carbon monoxide (CO) is produced by incomplete combustion of carbon from fossil fuels. CO emissions are a function of both the combustion efficiency and the post-combustion emission controls. Once released, the CO contributes to tropospheric ozone formation before the molecules can be further oxidised to $\mathrm{CO}_{2}$ through natural processes in the atmosphere. When OSVs are at the pier, these emissions add to the already-degraded air quality conditions. At each platform in the Campos Basin, the water is sent to a WWTP after use and is then discarded at sea without any reuse (Figure 1).

The most common type of WWTP used by the offshore oil platforms in the Campos Basin is a system of electrolytic units. The WWTP works by using electrolytic oxidation of organic material that has been injected with sodium hypochlorite generated in a cell that uses energy and seawater for this purpose. The WWTP then applies a biological treatment based on the degradation of organic matter by aerobic digestion.

The quality of the wastewater treated on the platforms in Brazil must meet the recommendation presented in the CONAMA Resolution 430/2011 [14] and in the MEPC 159 (55) Revised Guidelines on Implementation of the Effluent Standards and Performance Tests for Sewage Treatment Plants adopted on 13 October 2006 [15]. The main standards in the effluent are described in Table 1.

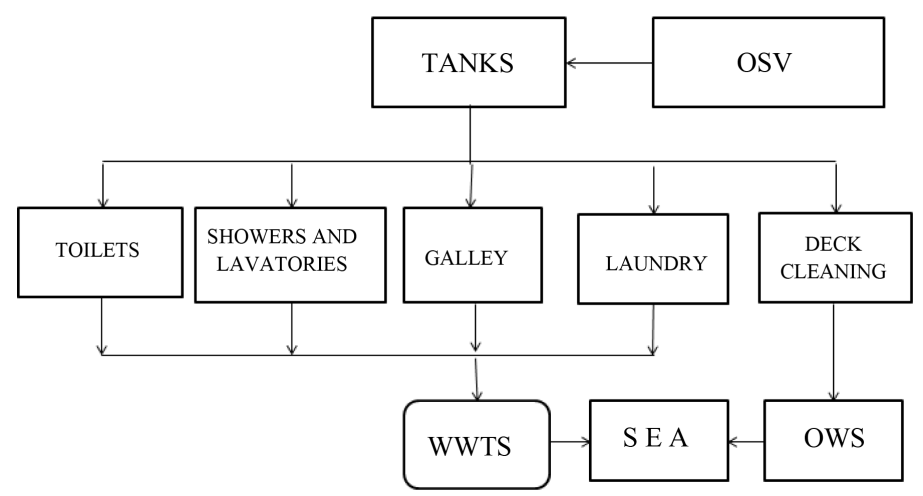

Figure 1. Simplified diagram without water reusing (current). Source: Petrobras. 
Table 1. Effluent quality parameters and their standards.

\begin{tabular}{cc}
\hline Parameters & Standards \\
\hline Thermotolerant coliforms & $100 / 100 \mathrm{ml}$ \\
TSS & $<35 \mathrm{mg} / \mathrm{L}$ \\
BOD & $\leq 25 \mathrm{mg} / \mathrm{L}$ \\
COD & $\leq 125 \mathrm{mg} / \mathrm{L}$ \\
pH & Between 6 and 8.5 \\
Residual chlorine & $\leq 0.5 \mathrm{mg} / \mathrm{L}$
\end{tabular}

Source: IMO, 2006.

The oily water generated on the platforms after passing through a water and oil separator (WOS) is discarded at sea when its concentration is equal to or less than 15 ppm. Under these conditions, the effluent from the WOS can be sent to the biological WWTP, where the oil can be degraded (in small concentrations) by the existing microbiota. This procedure has been used in many industries to avoid oil discharge in the environment.

\section{Material and Methods}

This study focused on the drilling and production platforms in the Campos Basin area belonging to Petróleo Brasileiro S/A Petrobras. It addressed the evaluation of fuel consumption by OSVs in the transportation of water to the 60 platforms of the studied region, the respective amounts of air emissions, and the chlorine discharges of effluents from wastewater treatment plants, in addition to presenting some water reusing possibilities.

To quantify the amount of fuel consumed via water deliveries, it was necessary to consider the conditions of ODM consumption and the time spent in each stage representing the water transport process via OSVs. The permanence of the OSVs at the pier that is to be supplied with water, the amount of time the OSV is beside the platform discharging the water and the respective operating speeds of the motors are known and typically do not undergo changes. However, the main limitation of this study was due to the variations of the time spent, and therefore the fuel consumption, in the following situations: on round trips to and from the platforms, waiting for authorisation to discharge water and travelling between platforms. To solve this problem and ensure that the data was as close to reality as possible, information was collected using the Petrobras logistics for some companies that rent OSVs, as well as the data from the platforms in the Campos Basin. The most frequent times at each step of the process and their engine operating systems were used for the calculations of this study (Table 2).

The methodology used to estimate the generation of gases and particulate matter are in accordance with the Revised 1996 Guidelines of the IPCC for Inventories National Greenhouse Gases, which recommends that shipping emissions be estimated by multiplying the amount of fuel used by an appropriate emission factor (EF) (IPCC DEFAULT EMISSION FACTORS FOR SHIPS AND BOATS US) [9] [13] [16].

The emission factors (EF) used are detailed in Table 3.

In the proposed reusing system of black water and dark grey water, organic matter degradation occurs by biological processes. After disinfection by ultraviolet light, the stream receives a small dose (2 mg/L) of chloride to maintain a residual amount in the storage tank. This water is reused and used in the discharge vessel, for deck cleaning, as a replacement for evaporated water, and in industrial equipment. The water that is not used it is discarded at sea after passing through an activated carbon filter, preventing chlorine discharge into the environment. The light grey water and black water are completely reused, and therefore, it is not discarded at sea. Similar to reusing black water, after treatment, the light grey water is disinfected with UV and is given a $2 \mathrm{mg} / \mathrm{L} \mathrm{dose} \mathrm{of}$ chlorine with the same goal as previously mentioned.

\section{Results}

Given the needs of each platform and the logistics of drinking water transportation, on each trip, OSVs carry $2000 \mathrm{~m}^{3}$ of water that is prorated equally for four platforms (500 $\mathrm{m}^{3} /$ travel/platform). Because each platform consumes $50 \mathrm{~m}^{3}$ of water per day, the OSV must carry water every 10 days.

The total MDO consumption per year for 60 platforms is the total consumption per trip (33.45 tons) (Table 3) 
Table 2. Mean time and engine oil consumption for each step of water delivery to the four platforms.

\begin{tabular}{cccc}
\hline CONDITIONS & TIME SPENT (h) & ODM CONSUMED (Ton/h) & TOTAL ODM CONSUMED (Ton) \\
\hline On the pier & 5 & 0.072 & 0.36 \\
Outward voyage & 12 & 0.727 & 8.73 \\
Waiting on the way & 24 & 0.270 & 6.48 \\
Between platforms & 9 & 0.727 & 6.54 \\
Discharging water & 20 & 0.288 & 5.76 \\
Waiting on the trip back & 10 & 0.270 & 2.70 \\
Travel back & 10 & 0.288 & 2.88 \\
Total & & & 33.45 \\
\hline
\end{tabular}

Source: Field data.

Table 3. Emission factors.

\begin{tabular}{ccc}
\hline GASES & FE Kg/ton de DMO \\
\hline $\mathrm{CO}_{2}$ & 3188 \\
$\mathrm{NO}_{\mathrm{x}}$ & 63.1 \\
$\mathrm{CH}_{4}$ & 0.23 \\
$\mathrm{~N}_{2} \mathrm{O}$ & 0.08 \\
$\mathrm{NMVOC}$ & 4.9 \\
$\mathrm{CO}$ & 21.3 \\
$\mathrm{SO}_{2}$ & 20 \\
$\mathrm{PM}$ & 1.5 \\
\hline
\end{tabular}

Sources: [9] [13] [16]. DMO: Diesel Maritime Oil.

times the annual number of trips (540). So, the total consumption of MDO in 2013 was 18,064 tons.

Using the EF (Emission Factors) and the total MDO consumption for a year, the quantities of generated gases and particulate matter were determined. Therefore, Table 4 shows the estimated total amount of $\mathrm{CO}_{2}, \mathrm{NO}_{\mathrm{x}}, \mathrm{CH}_{4}$, $\mathrm{N}_{2} \mathrm{O}, \mathrm{NMVOC}, \mathrm{CO}, \mathrm{SO}_{2}$ and PM generated in 2013 by the 23 OSVs that transport drinking water for the 60 platforms in the Campos Basin-RJ-Brazil belonging to Petrobras.

The electrolytic WWTP installed on the platforms in the Campos Basin discard up to $50 \mathrm{mg} / \mathrm{L}$ of hypochlorite per litre of effluent generated [17]. To treat $50 \mathrm{~m}^{3}$ per day of wastewater/platform, $2.5 \mathrm{~kg}$ of sodium hypochlorite is produced. Therefore, in 2013, the generation to 60 platforms resulted in 54.75 tons of sodium hypochlorite. In the reusing of effluent water consumed in offshore platforms in the Campos Basin, the best way to reuse water is to separate the effluent into two streams: a black water and dark grey water and the other with only light grey water (Figure 2).

The chlorine disposal from the biological units is 0.5 to $1 \mathrm{mg} / \mathrm{L}$, while the electrolytic units reach $50 \mathrm{mg} / \mathrm{L}$ [17], which is 50 - 100 times greater, thereby generating a more significant environmental impact if it is not adequately neutralised using sodium metabisulfite. Chlorine neutralisation requires the purchase of equipment and chemicals, as well as storage and handling, which is aggravated in electrolytic units due to the high concentration of chlorine in the effluent.

The main tasks of the OSVs in the Campos Basin are carrying water, food, diesel fuel and parts for offshore platforms. However, the vessels that carry water are not the same vessels that transport the diesel oil. Therefore, by reusing water, the food supply can be transported in smaller vessels with low ODM consumption, resulting in fewer atmospheric emissions. If the same vessel is used for both water and food, and reused water being used for $70 \%$ of the total water consumption, the water supply via the OSV can be made every 30 days instead of 10 days. Therefore, every step of the current water supply procedures can be reduced in the same proportion, that is, considering the 18,064 tons consumed in 2013 , with reusing, the annual water consumption can be reduced by 
Table 4. Amount of gas and PM issued.

\begin{tabular}{cc}
\hline GASES & Ton \\
\hline $\mathrm{CO}_{2}$ & 57,587 \\
$\mathrm{NO}_{\mathrm{x}}$ & 1140 \\
$\mathrm{CH}_{4}$ & 4.15 \\
$\mathrm{~N}_{2} \mathrm{O}$ & 1.45 \\
$\mathrm{NMVOC}$ & 89 \\
$\mathrm{CO}$ & 385 \\
$\mathrm{SO}_{2}$ & 361 \\
$\mathrm{PM}$ & 27 \\
\hline
\end{tabular}

Source: Field data.

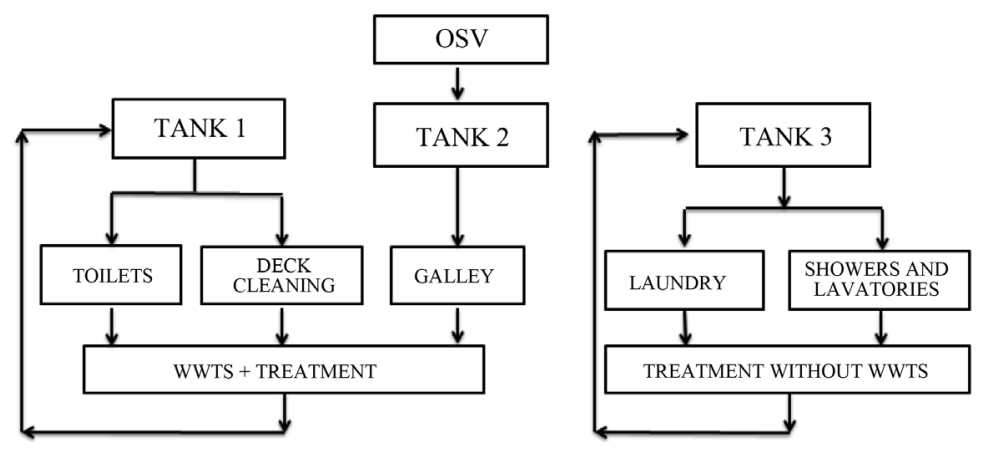

Figure 2. Simplified diagram of water reusing. Source: Author.

\section{2,645 tons of MDO (Figure 3).}

As a consequence of water reusing, there is a 70\% reduction in MDO consumption. The emissions reduction is presented in Table 5 .

The seawater desalination by reverse osmosis or distillation processes, despite being widely used, have operation and maintenance problems, with the main one being the formation of barnacles in the water catchment pipes [18]. On the other hand, to meet an offshore platform's daily consumption needs, it is necessary to treat 50 $\mathrm{m}^{3}$ /day of seawater with a salinity ranging from 33,000 ppm to 37,000 ppm [19]. This process results in 1.5 tons/day of salt residues being generated. This amount of salt is too aggressive for the reverse osmosis membranes and the internal parts of the distillers [20] [21].

Regarding the current condition, the reusing of effluent from offshore platforms in the Campos Basin can provide:

1) Macaé River conservation, ensuring greater availability of water for the local population, representing a savings of $766,500 \mathrm{~m}^{3}$ of water per year, which is enough to supply 14,000 people per day, considering a daily per capita consumption of 150 litres.

2) A reduction of the annual consumption of 33.2 tons of aluminium sulphate in the WTP.

3) The prevention of the generation of 47.25 tons of sludge/year in the WTP, which otherwise would have to be transported and incinerated.

4) Minor emanations of OSVs at all stages of the water transportation to the platforms.

5) Elimination of oily waste disposal at sea.

Water reusing and changing the treatment of domestic wastewater from electrolyte to biological-based treatment avoids the disposal of 54.75 tons of chlorine into the sea each year.

\section{Discussion}

Using desalination to supply seawater to offshore platforms is already a global reality. However, despite the fact that reusing water for use on offshore platforms is more favourable compared to desalination, water reusing 


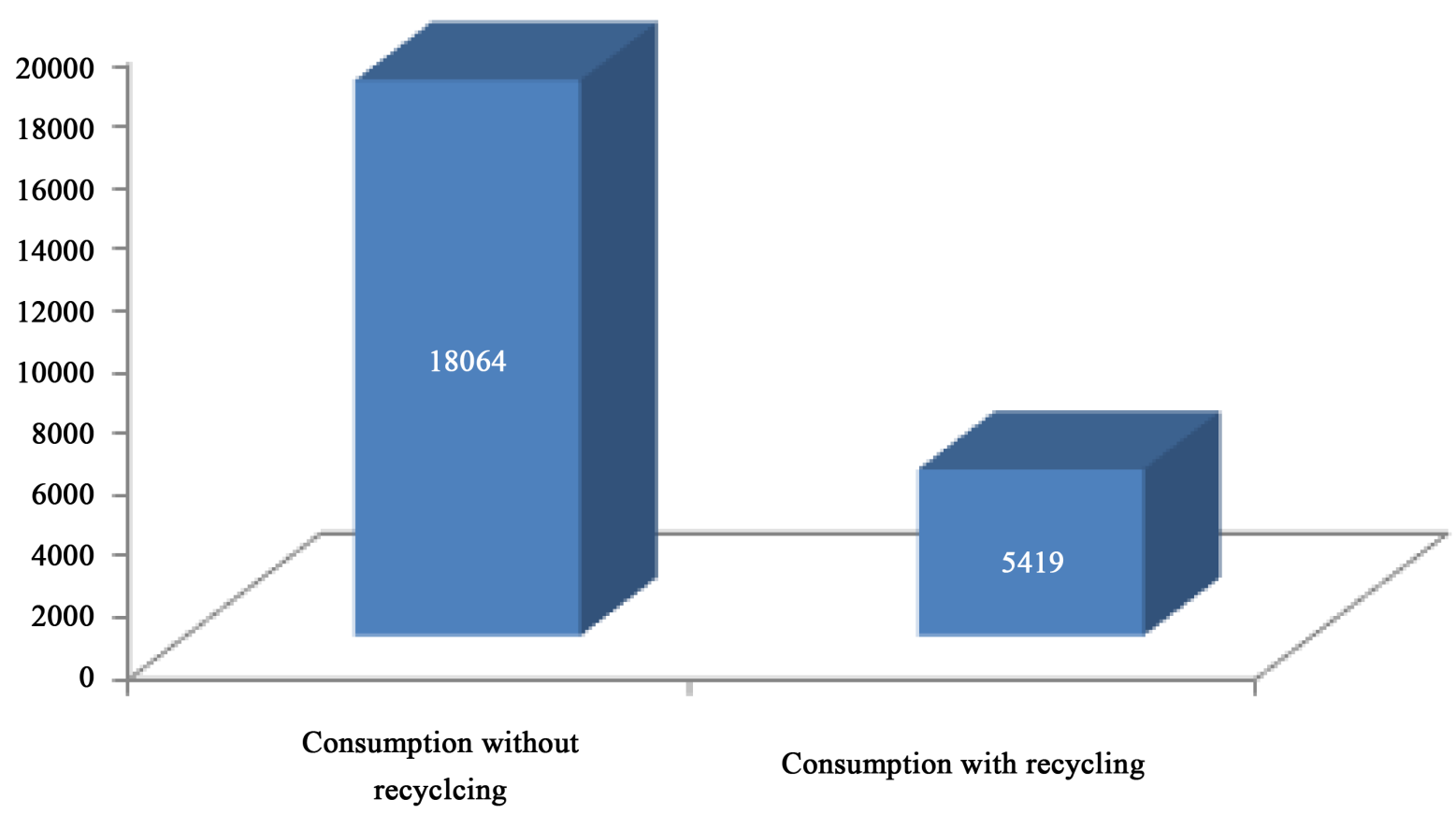

Figure 3. Annual DMO consumption (ton) without reusing and after water reusing. Source: Field data.

Table 5. Reducing emissions by reusing the effluent.

\begin{tabular}{cc}
\hline GASES & ton/year \\
\hline $\mathrm{CO}_{2}$ & 40.311 \\
$\mathrm{NO}_{\mathrm{x}}$ & 798 \\
$\mathrm{CH}_{4}$ & 2.9 \\
$\mathrm{~N}_{2} \mathrm{O}$ & 1 \\
$\mathrm{NMVOC}$ & 62 \\
$\mathrm{CO}$ & 269 \\
$\mathrm{SO}_{2}$ & 253 \\
$\mathrm{PM}$ & 19 \\
\hline
\end{tabular}

Source: Petrobras and calculations with field data.

has not been widely adopted. The transport of water via an OSV avoids the drawbacks of seawater desalination. However, when the operational, logistical and environmental aspects of desalination are compared with the reusing of sewage, the latter is the better option.

Regarding the choice of WWTS, the electrolytic units are lighter and more compact than are the biological units, making the units advantageous on offshore platforms, where space and weight are crucial considerations for the installation of equipment. However their operational, maintenance and legal limitations point to biological WWTP as being the better option. Furthermore, the reusing proposal allows for the size reduction of the biological WWTP to be used, since the light grey water is reused without going through the WWTP. This reduces the weight and footprint of a biological WWTP that can handle all types of water (light grey water, dark grey water and black water). Finally, with water reusing, small amounts of chlorine will be used $(2 \mathrm{mg} / \mathrm{L})$ in the biological WWTP effluent after sand filtration and UV light just to maintain a disinfectant residual in the storage tank. However, the electrolytic WWTPs that handle sodium bisulfite and the tank installation for its storage require the chlorine generation to be neutralised to $50 \mathrm{mg} / \mathrm{L}$ in these units.

By reusing water, the environmental impacts are reduced due to the reduction of the OSVs trips, benefitting 
the local population of Macae City, as well as the global environment, due to the reduction of large amounts of $\mathrm{CO}_{2}$ emissions.

The installation of water reusing equipment requires regular maintenance, which is time consuming and necessitates having a qualified person available for this. However the time currently spent in the OSV discharging water to the platform, which takes $5 \mathrm{~h}$, involves having three people every 10 days, totalling 45 hours of work per month. On the other hand, the maintenance of the water reusing system equipment will require only one person and two hours per week, which reduces the number of people necessary for managing the platforms (Table 6).

The study showed that by using a reverse osmosis treatment in the process of reusing water effluent from showers and laundry, the concentration of total dissolved solids (TDS) is much smaller than is the amount of salt $(33.000 \mathrm{mg} / \mathrm{L})$ when seawater is used to provide water. Therefore, reusing grey water allows for less wear of the membranes and lower amounts of solid waste if distillation is preferred. On the other hand, the waste generated by reusing grey water is organic and may be directed to the biological digestion in the WWTP, avoiding discharge into the environment (loss of water), which does not occur in the desalination of seawater. However, it is still more economical, effective, and environmentally friendly to install additional equipment to process the effluent to meet technical requirements than it is to keep the current system of supplying water via OSV.

\section{Conclusions}

Due to water scarcity in some regions and its high cost to transport to certain locations, such as on offshore platforms, water reusing a viable alternative solution. This practice also allows for the preservation of water resources that currently being exploited at increasing rates. This study demonstrated that there was a big difference between using OSVs to transport water to offshore platforms in Campos Basin and the effluent recycling from wastewater. In this case, effluent reusing helps to minimise the levels of both air emissions (especially greenhouse gases) and the harmful effects generated by OSVs. In addition, water reusing reduces the consumption of chemicals in the WTP, as well as the generation and incineration of sludge. Furthermore, water reusing protects the marine environment, since it minimises the use of the current method where effluent is disposed into the sea.

Furthermore, the reusing of effluent is also an option for consideration in strategies used for lowering costs in the drinking water supply chain, which is currently done via the use of OSVs. For this to be achieved, changes in water management should be made in order to improve its use, reducing the risk of water shortages caused by OSV limitations. Besides being more feasible, water reusing is one of the best options for optimising water preservation efforts. Therefore, it is preferable to reuse the effluent from the WWTP rather than to meet all water needs using the OSVs. This will leave more water for the population of Macae city, which uses the same water source for their consumption and already is experiencing difficulties in water supply. In this context, the implementation of a system that allows for the reusing of effluent, which shall undergo disinfection based on known techniques before being tested and approved, is relevant.

The investment in systems for effluent reusing provides a rapid return of the invested capital, given the high costs both of transporting drinking water by OSV and using systems for the catchment and treatment of water in Macaé city.

Water reusing will also significantly reduce the climate and sea conditions that could make it impossible for OSVs to supply water due to shipping difficulties. It will also result in a reduction of $\mathrm{NO}_{\mathrm{x}}, \mathrm{SO}_{2}$ and particulate

Table 6. Maintenance and runtime.

\begin{tabular}{|c|c|c|c|}
\hline ACTIVITIES & ESTIMATED TIME & TYPE & FREQUENCY \\
\hline Visual inspection & $60 \mathrm{~min}$ & Inspection & Weekly \\
\hline Sand Filter Backwashing & - & Automatic & According to the operation \\
\hline Micro Filtration Drainage & - & Automatic & According to the operation \\
\hline UV Cleaning & $30 \mathrm{~min}$ & Manual & Weekly \\
\hline RO Drainage & - & Automatic & According to the operation \\
\hline Replace Chlorine Tablets & $30 \mathrm{~min}$ & Manual & Weekly \\
\hline
\end{tabular}


emissions from OSVs, having beneficial impacts mainly on the air quality. The goal of environmental efficiency is to maintain the same activities while using fewer emissions, preserving the water sources. Reusing of the effluent is the main alternative, which presents increased opportunities to supply water efficiently. However, with the drastic reduction of OSV-dependent water, distribution logistics for other material being shipped to the platforms should be reviewed in order to reduce the current fleet and costs.

Finally, given the advantages of reusing, future platforms and offshore vessels focused on the exploration and production of oil can be planned with these considerations in mind. They should be designed taking into account procedures for water reusing, separating the streams of grey and black water in order to facilitate the process, expanding the possibilities of reusing, reducing energy consumption, lowering operating costs, and preserving the environment.

\section{References}

[1] Lemos, F. (2013) Personal Communication.

[2] Sanabra, M.C., Santamaría, J.J.U. and De Osés, F.X.M. (2013) Manoeuvring and Hotelling External Costs: Enough for Alternative Energy Sources? Maritime Policy \& Management: The Flagship Journal of International Shipping and Port Research. http://www.tandfonline.com/doi/abs/10.1080/03088839.2013.782441\#.UhumC9K-owA

[3] Aas, B., Sr, Ø. and Wallace S.W. (2009) The Role of Supply Vessels in Offshore Logistics. Molde University College, The Norwegian School of Logistics. Maritime Economics \& Logistics, 11, 302-325. http://dx.doi.org/10.1057/mel.2009.7

[4] Rem Ship (2013) Rem Leader VS 499 LNG PSV Platform Support Vessel. www.rem-maritime.no

[5] Williams, E., Lerner, B. and Murphy, P. (2009) Determination of Emission Factors from Commercial Marine Vessels NOAA/ESRL/CSD, Boulder, CO 80305 and CIRES/University of Colorado, Boulder, CO 80309. http://www.epa.gov/ttnchie1/conference/ei17/session4/williams.pdf

[6] Eyring, V., Isa, I., Berntsenc, T., Collins, W.J., Corbett, J.J., Endresenf, O., Grainger, R.G., Moldanova, J., Schlage, H. and Stevensoni, D.S. (2009) Transport Impacts on Atmosphere and Climate: Shipping. Atmospheric Environment. http://www.geos.ed.ac.uk/ dstevens/publications/eyring ae09.pdf

[7] Eyring, V., Corbett, J.J., Lee, D.S. and Winebrake, J.J. (2007) Brief Summary of the Impact of Ship Emissions on Atmospheric Composition, Climate, and Human Health.

http://www.pa.op.dlr.de/ VeronikaEyring/Eyringetal_IMOBriefSummary_FINAL.pdf

[8] Petróleo, D. (2009) Óleo Diesel Marítimo. http://www.dipelpetroleo.com.br/oleos-diesel.aspx

[9] Lima, P.C.R. (2004) Gas Natural: Uma importante alternativa energetica para o Brasil Biblioteca Digital da Camara dos Deputados. http://www2.camara.leg.br/documentos-e-pesquisa/publicacoes/estnottec/pdf/2004 2717.pdf

[10] Dkrz, D.K. (2014) Particulate Matter from Ship Emissions. Regional Chemistry Transport Model: Pollutants from Ship Emissions. http://www.dkrz.de/about-en/media/galerie/Vis/regional/feinstaub

[11] Benkovitz, C.M., Berkowitz, C.M., Easter, R.C., Nemesure, S., Wagener, R. and Schwartz, S.E. (1994) Sulfate over the North Atlantic and Adjacent Continental Regions: Evaluation for October and November 1986 Using a Three-Dimensional Model Driven by Observation-Derived Meteorology. Journal of Geophysical Research, 99, 20725-20756. http://dx.doi.org/10.1029/94jd01634

[12] Corbett, J.J. and Winebrake, J.J. (2007) Emissions Tradeoffs among Alternate Marine Fuels: Total Fuel Cycle Analysis of Residual Oil, Marine Gas Oil and Marine Diesel Oil. Journal of the Air and Waste Management Association.

[13] Jun, P., Gillenwater, M. and Barbour, W. (2000) $\mathrm{CO}_{2}, \mathrm{CH}_{4}$, and $\mathrm{N}_{2} \mathrm{O}$ Emissions from Transportation-Water-Bourne Navigation. http://www.ipcc-nggip.iges.or.jp/public/gp/bgp/2_4_Water-borne_Navigation.pdf

[14] Brasil, Ministério do Meio Ambiente (2011) RESOLUÇÃO CONAMA No 430 de 13 de Maio de 2011. http://www.cetesb.sp.gov.br/agua/praias/res_conama_357_05.pdf

[15] IMO, International Maritime Organization (2006) MEPC 159 (55) Revised Guidelines on Implementation of Effluent Standards and Performance Tests for Sewage Treatment Plants. Adopted on 13 October 2006. http://www.imo.org/OurWork/Environment/PollutionPrevention/Sewage/Documents/Resolution\%20MEPC.159-55.pdf

[16] Trozzi, C. (2011) Emission Estimate Methodology for Maritime Navigation. Roma. http://www.epa.gov/ttnchie1/conference/ei19/session10/trozzi.pdf

[17] Upsher, F.J. and Fletcher, L.E. (1996) Review of Chlorine and Organohalides and Their Significance to the Royal Australian Navy. http://dspace.dsto.defence.gov.au/dspace/handle/1947/3916

[18] Franks, R., Wilf, M., Voutchkov, N., Murkute, P. and Kizer, J. (2011) A Pilot Study Using Seawater Osmosis Membranes in Combination with Various Pretreatments to Meet the Challenges of Pacific Seawater Desalination. 
http://www.membranes.com/docs/papers/New\%20Folder/A\%20PILOT\%20STUDY\%20USING\%20SEAWATER\%20 REVERSE\%20OSMOSIS\%20MEMBRANES.pdf

[19] Ladewig, B. and Asquith, B. (2011) Desalination Concentrate Management. Springer Heidelberg, Dordrecht, London and New York.

[20] Chesters, S.P., Penna, N., Gallego, S., Fazel, M., Armstrong, M. and Del Vigo, F. (2011) Results from 99 Seawater Ro Membrane Autopsies. http://www.genesysro.com/uploads/docs/PER11-297.pdf

[21] Guasp, R.E., Jara, C.P.B., Garcia, J., Veja, J.P., Damien, T., Winkle, C. and Smith, H.H. (2005) Desalination by Distillation. https://www.oas.org/dsd/publications/Unit/oea59e/ch21.htm 